\title{
African bureaucracy and public administration: Analysing the normative impediments and prospects
}

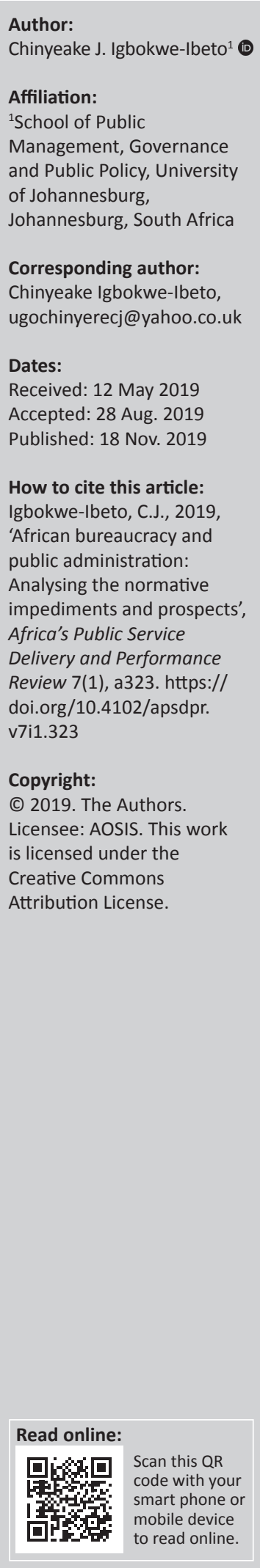

Background: Public perception of bureaucracy and public administration is key to determining how much they can accomplish in a given environment. The pejorative view of bureaucrats and public administrators is not restricted to Africa. Although they are sometimes seen as one and the same, analytically they can be divorced.

Aim: Within the framework of system theory, this article analysed the interface between African bureaucracy and public administration with the aim of identifying its impediments and prospects.

Setting: Relevant sources of this research were fairly and professionally scrutinised, understood and tested with the available literature for the research purpose. Inter alia, it included scanreading, comprehensive and critical reading and writing down ideas. Authoritative scholarly sources were reviewed during a desktop study. The purpose was to identify the relevant publications and apply them in the research.

Methods: This article utilised qualitative research design and descriptive methods to gain an insight into the nature and character of African bureaucracy and public administration. It is also exploratory because the article attempts to explore the nexus between African bureaucracy and public administration.

Result: This article argues that African bureaucracy is losing its potency and ability to give intellectual leadership to public administrators. Bureaucrats in the field rely too much on discretion that often does not sit well with the people and result in poor service delivery.

Conclusion: It therefore concludes that the poor state of affairs in African bureaucracy could change if the bureaucracy opens up to administrative reforms, particularly those that add value to their activities and actions. In this era of globalisation, international best practices should be domesticated.

Keywords: Africa; public administration; bureaucracy; impediments; prospects.

\section{Introduction}

Modern governance requires coordinated efforts of critical elements in the public and other sectors of the society to achieve its essence. As society expands to embrace bigger and more complex activities and actions, it has become increasingly imperative for the principal institutions of public management to be on top of challenges of the state. These challenges include building human capital for more creative and innovative development, better delivery of services, urban management, environmental sustainability, disciplined fiscal operations, appropriation of global best practices that would ensure better welfare and well-being of the people, among others (Akhakpe 2014:326; Dibie 2014:75; Igbokwe-Ibeto 2018:52).

All these activities require a crop of competent, well-trained and motivated workers in human resources at various levels of government. Such assemblage of creative talents is said to be found in the formal bureaucracy or top hierarchy of the civil service of every nation (Akhakpe 2014:326). They are expected to bring their creative talents to bear on the operations of government policies, programmes and activities. There is a sense in which we can say that the formal bureaucracies are the think tanks of public administration, particularly when it has to do with initiating quality ideas to drive the various businesses of modern government (Igbokwe-Ibeto 2017:108; Starling 2013:43).

Events in the world sometimes move at jet speed that unless government is proactive enough, it might be caught stranded. This seems to be the case in much of Africa today where government, as agents of the various state, works in several areas to meet the needs and aspirations of the people and the demands of a modern state. The various crises of governance that inundate the 
African continent are eloquent testimonies of the supposed failure of the bureaucracy to provide policy direction in various aspects of public administration.

This article seeks to examine the role of the bureaucracy in promoting public administration in developing countries, with Africa as a platform for analysis. The article also examines the constraints facing a bureaucracy in facilitating efficient and effective public administration. Finally, it dwells on prescribing recipes for change and transformation of their roles for national growth and development.

In analysing the issues raised, this article is divided into the following parts. Firstly, it indulges in conceptual and theoretical exploration. Secondly, it discusses the properties of the bureaucracy and public administration, how they have evolved over time and the trend all over the world in their various domains. Thirdly, it examines the interface between bureaucracy and public administration, how they dovetail into one another. Fourthly, it analyses the various constraints they face when viewed against the realities of the time. Finally, it compiles a tentative recipe for making the bureaucracy and public administration complementary to and promote development in the polity.

\section{Methodology}

This article utilised qualitative research design and descriptive methods to gain an insight into the nature and character of African bureaucracy and public administration. It is also exploratory because the article attempts to explore the nexus between African bureaucracy and public administration. Subsequently, relevant sources of this research were fairly and professionally scrutinised, understood and tested against the available literature for the research purpose. Inter alia, it included scan-reading, comprehensive and critical reading and writing down ideas. Authoritative scholarly sources were reviewed during a desktop study. The aim was to identify the relevant publications and apply them in the research.

\section{Conceptual and theoretical exploration}

Bureaucracy is the most visible branch of the executive arm of government, which is responsible for putting into effect government policies and programmes and the provision of goods and services to the people (Akhakpe 2014:84). Having defined the concept of bureaucracy, how exactly relevant is bureaucracy to public administration? Its importance can be observed from several angles. A peep into a few of them will be in order here! From a technical point of view, formal bureaucracy is head and shoulders above its homologue. It is characterised by elements that endear it to many and allow it to achieve goals consistently over a long period of time. Some of its mechanisms are interpersonality, hierarchy of authority, precision, specialisation and discipline, among others (Akhakpe 2014:327; Dibie 2014:13). All these elements have been tested and now trusted by most large public and private sector organisations. As an administrative organisation, bureaucracy is so influential that it is inescapable. Krygier (1998) cited in Sharma, Sadana and Kaur (2012) notes that:

$[A] \mathrm{s}$ an administrative organization found in every land of enterprise, its influence is more pervasive than other carriers of its rationality of the modern world and as the most advanced form of administrative organization, it is stronger, more escape proof, than any previous form. (p. 102)

Apart from the technical knowledge it avails to its users, it has been found to be the best means of exercising control over human beings in the workplace. Man is one social being who is difficult to control. For nearly everywhere leaders are looking for means to manage the human factor because of its unpredictable nature. But bureaucracy by virtue of rules and pattern of authority it puts forward has managed to control those under it to to reach the expected goals (Akhakpe 2014:327). Other systems of authority, before it, could not achieve this feat. Hence, Weber's bureaucratic model has gained worldwide acceptance, at least, as a form of arranging organisations to achieve results (Starling 2013:48). Unsurprisingly, its form and substances are found, although in varying degrees, in churches, the armed forces, hospitals and so on.

Therefore, its technical knowledge and rational system, among other traits, are invaluable to an effective public administration. In this modern age, if public administration is to realise its goals, it needs to draw its strength and inspiration from civil bureaucracy (Igbokwe-lbeto, Ajulor \& Afegbua 2012:106). Meanwhile, it is imperative to remind us of what public administration actually means. Perhaps, because of its centrality in modern society, there is a plethora of views of what public administration means. A review of some of them will suffice here.

Administration is as old as mankind itself. Its age-long antecedence can be traced to the effort of Homo erectus to survive (Akhakpe 2014:329). Through individual and group efforts they started recording one break through or the other. Without working together, it would have been difficult to come up with new discoveries. This point can be observed in the viewpoint of Gladden (1987) in Polinaidu's (2011) of the concept of administration when he posits that:

... administration is a long and slightly pompous word but has a humble meaning, for it means to care for, look after people or manage affairs ... is determined action taken in pursuit of a conscious purpose. (Simon 1976:87)

The element of caring for others through service is embedded in his view of administration. But for this endeavour to yield dividends, it has to be consciously pursued. Similar rendition is found in Simon's (1976) view on this subject when he claims that in its broadest sense, administration can be defined as the activities of group cooperating to achieve common goals. Administration is, therefore, a cooperative action involving human and material resources to achieve set goals or desired ends. 
When these activities are carried into the public domain, what comes to the forefront, is public administration. To Woodrow (1887) in Dibie (2014:15), public administration is a detailed and systematic execution of laws. Every particular application of law is an act of administration. He went on to posit that administration is the most obvious part of the government, it is the government in action: it is the executive, the operative, the most visible side of the government. Staying on the official side to the subject of public administration, Dwight Waldo (1987) in Laxmikanth (2011) opines that 'public administration is the act and science of management as applied to the affairs of the state'. Pfiffner (1986) in Sharma et al. (2012) contends that public administration consists of doing the work of government whether be it running an $\mathrm{x}$-ray machine in a health laboratory or counting money in the mint.

As per earlier discussion, what rapidly comes to the forefront in these views is that public administration can be seen as an art or science discipline. The debate has been going to and fro, but it is better to remain on a pragmatic level. As Kettl (2018), Sharma et al. (2012) and Denhardt and Blanc (2014:45) rightly observed:

... public administration is a progressive science where generalization or principles are bound to be constantly revised and restated on the light of fresh discovery of facts and new experience. There can be no absolute finality about the lessons it teaches, although, the various points of view put forward from time to time may give the student a truer and truer insight into the problems involved.

This is a more convenient point to leave the subject and move on because there may never be a winner over this issue among the gladiators in this contest.

Another issue that has not lent itself a position, generally agreed upon, in public administration as a field of study is the question of the theoretical approach that adequately captures the issues involved in public administration. Several theoretical orientations have emerged over time without anyone gaining ascendancy. There are, among others, bureaucratic, system, institutional, political economy and public choice theories. Despite newer theories on public administration like the public choice theory and new public management, the institutional and system theories remain relevant for our level of development on the African continent. It is only logical that a child should learn to crawl before he or she walks. Most African states have not mastered the act of respecting organisational legal rules and regulations, let alone to embrace rational choice in making public policy. In addition, illiteracy is still very high; conservative figure put it at $75 \%$ of the population. The ability of public officials to follow institutional rules and regulations is an important starting point to respect other demands of organisations (Anderson 1997; Milakovich \& Gordon 2013:114).

Nicholas (2010:89) and Jung (1991) argued that the system theory and all its shortcomings provide us a veritable tool to unlocking numerous questions that public administration raises in modern times. Analysing public administration as a system proposes that it has different parts that should interact and be interdependent on each other. Katz and Kahn (1968) in Koehier, Anatol and Applbaum (1976) argue that the system theory is basically concerned with problems in the relationship of structures and their interdependences rather than the constant attributes of objects. Certainly, there is merit in analysing the whole part from the part because without the whole there cannot be the parts. Therefore, the system analysts are only interested in the parts as they relate to the whole.

Also, Robbins and Timothy (2011:204) and Huse and Bouditch (1965) in Koehier et al. (1976) use the system theory to understand and manage behaviour in organisations. They come to the conclusion that an organisation has many subsystems that are interrelated and interdependent. Therefore, they argue that an organisation can only be effective and efficient when it has '... the ability to adopt a sense of identity, the capacity to test reality and the ability to be well integrated and to simultaneously consider' three interrelated perspectives: (1) structural design, (2) flow and (3) the human factor. What comes across in Africa over the years is that structure in administrative and political systems is standing aloof and hardly interacting to ensure effectiveness and efficiency in their roles and responsibilities. This mostly accounts for why there is a lack of synergy between what government does in each ministry, department and agencies, operating as if they are in functional terms independent of one another (Igbokwe-Ibeto et al. 2012:109). All these factors go a long way in determining the success rates of public policies and programmes.

However, behaviouralists led by Easton (1953) in Rhodes (1988) have criticised institutionalists' preoccupation with formalism or legalism, which falls short of developing a systematic conceptual framework that could identify important variables and their relationship to one another. $\mathrm{He}$, therefore, found the study of political institutions weak on two important grounds. Firstly, he found that the analyses of laws and institutions have not been able to explain policy because they do not cover all the important variables (Rhodes 1988; Shafritz, Russell \& Borick 2013). Secondly, hyperfactionalism that is the concern of institutionalists can only lead to theoretical malnutrition because it neglects 'the general framework within which these facts would acquire meaning' (Rhodes 1988:58). Be that as it may, in the study of public administration in Africa, the institutional theory is still relevant, given the state of its practice in the continent. Institutions have rules and regulations for guiding them, and where they are followed, they lead to stability (Weber 1947).

\section{Public administration: The old and new vision}

Public administration has gone through metamorphoses aimed at perfecting its acts to achieve the goals of government. What has come to represent the old vision of public administration was essentially concerned with law and order 
in the society. It had limited interaction with the social needs of the people. This was also referred to as the watchman role, where government was more interested in maintaining peace and security within their territories. This notion of public administration was more prevalent during the colonial era. Under this system, government maintained a lean public service under an indirect rule system.

To a large extent, the colonialists were able to maintain this system until they granted independence to their colonial territories. Thus, this era was characterised by effectiveness concerns rather than efficiency particularly in the use of public funds (Akhakpe 2014:328). Before long, however, it became clear that this method can no longer be sustained because of its inadequacy in meeting the central concerns of both the government and the people. To a large extent, it can be said that public administration operated under an authoritarian system perhaps because the colonial administration was itself authoritarian in nature (Dibie 2014:15). It is little wonder that the public sectors have more in common with authoritarian regimes: centralised command structure, hierarchy of authority, discipline and procedures, among others.

These characteristics were left intact at independence and in the immediate post-independent years of African countries. Therefore, attempts to tinker or restructure the public administration to conform to current realities have experienced resistance from public servants in Africa (Igbokwe-lbeto et al. 2012:113). They are more inclined towards maintaining the existing structure that $a b$ initio was faulty. If the foundation is structurally bad, whatever is built on it cannot stand. This is exactly the case with public administration in developing areas of the world. But African leaders have gone ahead to initiate and implement reform agenda mostly from Europe and America to suit trends in this system. What is the nature of these changes and to what extent have they been embedded in this system of administration? Answer to these questions forms part of our discourse in the next section.

\section{The new public administration}

As the popular dictum goes, change is the only permanent thing in life. The world is dynamic and complex. Organisations and individuals are expected to keep track of changes taking place per second to remain relevant in the scheme of things. Given the defects identified in the old vision of public administration, it is only logical and natural that it embraces change. What is the direction of this change?

The new public administration (NPA) movement began in the 1960s and early 1970s. These were periods the world was caught up in an unexpected crisis that rocked the United States. Even academic disciplines like sociology, politics and so on were affected. The crisis gave rise to the questioning of the relevance and efficacy of old traditional public administration theories and the adoption of NPA. To Akhakpe (2014:332), this coincided with the period when public administration operates under the dogma of 'economy and efficiency'. This was considered inadequate for the role designed for it in the new dispensation it finds itself. Scholars of this era, such as Adamolekun (1982), Simon (1976) and Gulick (1969), were quick to raise the issues of values and ethics in public administration. The argument became that efficiency does not exhaust issues public administration deals with. For them the central concern for public administration is man, a complex category not always amenable to economic laws encapsulated in efficiency (Denhardt et al. 2014). They, therefore, requested that public administration should move from this restricted view to value-oriented administrative system.

From the late 1960s to the early 1970s to the 1980s, the ideals and ideas of the NPA remained on the front burner of intellectual conversation. Several conferences on public administration took place during this period; all aimed at finding ways public administration can help resolve the crisis of the time. On the substance of the NPA, Rumeth in Sharma et al. (2012) scribbled:

New public administration is concerned with phenomenological approach, conceptually, and with humanistic orientation motivationally. Its major thrust is on enhancing the role and capacity of the public administrative system to meet the challenges of, and to direct social change ... To a phenomenologist, an organization cannot exist independently of the image that it forms in the minds of the perceivers (including the client groups). Thus, the separation of value and facts is stunted ... (p. 43)

What the NPA attempts to do is to embrace new techniques for addressing the emerging challenges of an ever-changing world. Like development administration that preceded it, the NPA is also 'goal oriented' and 'change oriented'. In addition, NPA is process-led with emphasis on making public administration more positivist and activist in nature. Despite all these features of the NPA, there is still no theory on which all scholars in the discipline agree on.

But Colambiewski (1988) in Polinaidu (2011) has come up with three anti-goals of the NPA. These include the following:

- Anti-positivism: There is a strong current of the NPA against the positivist influence on public administration. The protagonists of this school of thought reject the view of value-free public administration. Also, public administration that is not involved in policy. For them, public administration should solve problems.

- Anti-technical: The NPA is opposed to sacrificing human beings to the logic of the machine. Man cannot be likened to a machine.

- Anti-bureaucratic and anti-hierarchical: The NPA is averse to bureaucratic and hierarchical structures of administrative organisations. Its proponents want to seea debureaucratised government with a more humane, flexible and democratised form of administrative organisation.

\section{Goals of the new public administration}

On the contrary, five positive perspectives have been put forward by the NPA. According to Igbokwe-Ibeto (2019:200), these include the following: 
- The NPA sees man as not static, but has potentials for becoming perfect.

- It stresses the importance of personnel and organisational values and ethics, high moral ground and the synergy between administrative structure, processes, and the ends and goals they want to achieve.

- They see social equity as the proper vehicle for human development. Social equity means that the NPA cannot afford to be neutral, rather it should be a champion and defender of the underprivileged section of the society. Public administrators should be agents of social change and economic growth. They should strive towards protecting and advancing the interests of the less privileged groups in the society.

- The NPA places premium on innovation and change. However, this would not affect other arms of government.

- The NPA proposes to be rational. It emphasises a clientcentred approach that not only harps on meeting client needs for quality goods and services but also giving them a voice in major decisions of what to be provided, when and how.

It is expected to prioritise the decentralisation of administrative processes in place of the bureaucratisation and democratisation of decision-making to facilitate the effective delivery of public services to the citizenry.

An evaluation of the debate will show that there is no clear winner. Both the protagonists and antagonists have their strong points. There is no doubt that public administration needs to be dynamic to be able to conform to changing conditions in the world. Yet, there is a lacuna between aspirations and performances in public administration. However, grounds have been broken and new standard set up, such as social equity and moral grounds for administering society. Nigro and Nigro (1968) cited in Sharma et al. (2012) clearly advocate of the NPA have stimulated constructive debate and their emphasis upon the positive moral goals of administration should have a lasting impact. Since the NPA emerged, questions of values and ethics have remained major items in public administration.

\section{Characteristics of bureaucracy and public administration}

Bureaucracy has remained an inevitable outcome of a large organisation, an indispensable element in publicadministration and an irresistible force in modem government. It is paradoxical that bureaucracy has come under strong criticism from all that is affected in one way or the other by its activities and actions. Yet, no one is ready to dispense with it, in a large organisation. Therefore, in a sense, bureaucracy can be regarded as a necessary evil. Arising from these views of the concept of bureaucracy is the point that the system harbours within it, good elements that should be identified and employed by managers of varied organisations across the face of the earth.

Weber's formulation of the ideal type bureaucracy perhaps was an answer to the puzzle of his time. There was a concern about how to deal with the challenge of the enlightenment era and problems created by the industrial revolution. The existing forms of authority fell short of what was required to deal with the crisis in this era because of their subjectivity and the uncertainty of rules and laws under them. Weber in an attempt to proffer a solution to what he saw as illegitimacy in this form of authority system came up with a prescriptive view of what bureaucracy should be. Weber's theory did not derive from any observed practice of the system, but views on what modern organisations should look like in terms of structure, norms and operations (Weber 1974). But his views were so convincingly marshalled that it appeals to all striving towards efficiency and effectiveness in an organisation. Dimock (1952) in Sharma et al. (2012) says that complexity produces bureaucracy.

Also, bureaucracy is legal-rational in nature. However, laws are clearly stated and known to its officials. And the reward or punishment that follows adherence to or disobedience of these rules and laws. In an ideal type bureaucracy, there is hierarchical ordering that is conducive to discipline in such an organisation. The absence of a system of autority makes giving of orders difficult. In these circumstance, chaos may be the inevitable outcome of bureaucratic operations.

Divisions of labour or the specialisation that we find in bureaucracy makes room for professionalism that may likely culminate in the increased performance and productivity of bureaucrats in the public sector. The article agrees with Sharma et al. (2012) that bureaucracy therefore seems to be an essential ingredient of modern civilisation. So, it is fruitless to argue whether we ought to, or ought to not have bureaucracy.

For analytical purposes, we find it apposite to segregate bureaucracy from public administration. In which case, we see bureaucracy as an element of public administration. To this end, given the opprobrious nature and odious connotation bureaucracy conjures in the hearts and minds of the people, itcan constitute a problem to public administration. If, from our understanding, these problems are inseparable from public administration, bureaucracy can then be seen as a process and element of administration.

\section{Significance of public administration}

Public administration is as old as government itself. But in modern times, public administration has assumed more roles and its significance has been extended to all aspects of societal and human lives. These roles have gotten even bigger and larger in the light of the emergence of the administrative state. Its activities and actions have become so far-reaching that society and the body polity cannot escape its impact. Thus, the significance of public administration is overarching. Some of its significance on the people and polity, according to Akhakpe (2014:343), can be highlighted, thus:

- it is the basis of government

- an instrument for implementing laws and policies

- a great stabilising force in society

- provides continuity and changes 
- gives legitimacy to the government in power

- promotes unity and nation building.

Public administration is the basis of government. We have seen from the analysis conducted in the preceding section that government cannot achieve its essential purpose in modern society without an array of public administrative structures and institutions that carry out an array of functions aimed at actualising the philosophy of government and its vision to the people and society. Public administration does not have bias for any particular regime. It serves any government that comes to power, be it ancient empire, monarchies in developed and developing countries, democratic and dictatorial systems.

Public administration has been a veritable tool for implementing the laws and policies of the government in power. By implementing the laws of the state, it ensures that there is moral order in society and that the behaviour of members of the society is in line with civilised norms. Also, by implementing public policies and programmes of government, it helps to fulfil governmental promises to the citizenry. The citizens of every country have high expectations of their government to provide the basic necessities of life such as water housing, education and security of lives and properties. While politicians may promise a lot in their electoral campaigns and may have a lot of resources at their disposal, without efficient and effective administration all these may end up as mere promises or paper work.

Another significant role public administration plays in the polity is that of maintaining and preserving the status quo in the society. This is particularly the case in developing countries of Africa, Asia, Africa and Latin America that are usually characterised by social tension, conflicts and political upheavals. The activities and actions of public administration help to promote social unity and harmony by moderating the corporation and temperament of members of the society. As Pigors (1982) in Polinaidu (2011) puts it as the administrative function, ensures the continuance of the existing order with a minimum effort and risk. Its fundamental function is to carry on rather than to venture along new and untried paths. Administrators are therefore the stabiliser of society and the guardian of traditions.

In addition, public administration continues the act of government and governance irrespective of the regime in power at any given point in time. Government may come and go; ministers may be changed either through cabinet reshuffle or revolution or coup d'tat but administrators remain. As Ramsay in Polinaidu (2011) opines:

... while government may come and go, ministers may rise and fall, the administration of a country goes on forever. No revolution can change it and no upheavals can uproot it. (p. 116)

But this development has led to a situation where public administration is slowed down by a new policy perspective and leadership style. This has been the case in most African countries where policies count for little, and changes of top administrators in the civil service, ministry and others occur too frequently.
Public administration helps to store up the legitimacy of government in power. The government in power needs legitimacy to remain there. And no government wants to leave power prematurely. It is the responsibility of public administrators to ensure that the seating government does not suffer a legitimacy crisis that may lead to its defeat at the next available elections. This would demand that public administrators sell the policies and programmes of the government very well and do their best to make sure that the expectations of the people from their governments are met. Sometimes, the clash of interest government officials, on the one hand, and the administrators, on the other, stagnate the performance of government, leading to low level of growth and development in the society (Akhakpe 2014:345).

The quest and hope for nationhood are largely on the shoulders of public administrators. Most countries in Africa are artificial creations by their former colonial masters. People of different background, religion and culture are foisted together in what could be described as a marriage of convenience. It behoves on public administration to wield these divergent groups and nationalities together into Nation States. This task has not been easy, but public administrators in most African states have taken the 'bull by the horns' to ensure that the course of nation building is maintained.

Public administration has been an instrument for social change and transformation in the polity. Public administration not only follows the will of the people whom it serves, but they also lead them in the direction that they perceive good and honourable. It drives the processes of socio-economic, cultural and political transformation of the society (Akhakpe 2014:344). It is the preserve of the transformation agenda of successive governments and administration fighting and combating a lot of ills in society such as inequality, poverty, school dropouts, human rights and other abnormalities that come with rapid changes in our complex world. A society, where public administration fails, is likely to descend into violence and other deviant behaviours such as religious insurgency, militancy, kidnapping, child trafficking and baby factories (where new born babies are sold), among others.

All these significance of public administration in modern societies may not be realised if the bureaucracy is not robust and properly linked to its administrative arm. What then is the relationship between these two? To this, the article shall direct its attention in the section that follows.

\section{The interface between civil bureaucracy and public administration}

There is a strong and direct relationship between civil bureaucracy and public administration. By civil bureaucracy here, we mean that top echelon of the civil service that provides intellectual leadership to the executive arm of government. It is that arm, where Max Weber's legal-rational system of administration mostly applies (Akhakpe 2014:346). 
Their traditional role is to advise government on proposed policies and programmes and give direction to policies once they are passed into law by the legislatures and political executives (Igbokwe-Ibeto \& Anazodo 2015:131).

This, according to Anderson (1997), means that the day-today discharge of the elements in any given policy is the prerogative of public administrators particularly those in the field. Thus, the actual implementation of the policies and programmes of government rest on public administrators or public servants. Perhaps, there is a thin line dividing the two, but analytically they can be disaggregated. Many of those involved in formulating policies are called bureaucrats. Theirs is to provide the technical knowledge, experience and skills garnered over time in the art of policy-making in the civil service (Akhakpe 2014:346).

Successive governments have had to rely on this crop of talented officials even when it is not in their interest to do so because of the stupendous experience they have in this specialised task and their ability to have their interests met irrespective of those held by their political bosses. Their influence, therefore, is enormous on the policy-making processes and actual implementation of government policies and programmes. According to Igbokwe-lbeto et al. (2012:106), the role of bureaucrats, therefore, is to give broad guidelines and directives on how best to implement government policies and programmes for the good of the government in power, the people and society at large.

It is important to note that civil bureaucracies have proliferated over time in line with the growth and expansion of government activities and actions. Thus, public administration has numerous bureaucracies serving is. Every large organisation has its own bureaucracy. Therefore, as new organisations are set up in government, they come each with their own bureaucracy. To Akhakpe (2014), Dibie (2014) and Igbokwe-Ibeto et al. (2012), this has been the trend in the public realm of most countries in Africa as they take up what ordinarily should be the responsibility of the private sector. Thus, theoretically, both may look the same, but analytically they need to be separated for proper discourse.

One can safely posit, therefore, that the relationship between civil bureaucracy and public administration is a symbiotic one as they complement each other's role in government. They are to be seen as partners in progress, not antagonists of one another. For the efficiency and effectiveness of modern government, they need to work hand in hand (Akhakpe 2014:345). One is to service the other with their repository of technical expertise, knowledge, skills and experience to better the act of governance that public administration carries out. As Lapalombara (1974) argues, if we regard civil servants as those:

... directly involved in providing basic governmental services, conceived in this somewhat restricted way, one would exclude all public employees who are engaged in direct participation in industry, agriculture, mining, forestry and fishing and in-service activities associated with the so-called tertiary sector. (Akhakpe 2014:347)

Suffices to say that this may be a neat classificatory scheme, but it only manages to convey the basis for separating the two concepts practically.

Africa has had reasonable post-independence years to enable one to assess the contributions of public administration to the development of the continent. Yet, what comes across to any cursory observer of development on the continent is that there is much left undone by the public administration system.

\section{African bureaucracy and public administration: The normative impediments}

Public perception of bureaucracy and public administration is key to determining how much they can accomplish in a given environment. The pejorative view of bureaucrats and public administrators is not restricted to Africa. It is a universal phenomenon. This means that the only way to deal with it is to leave with it. Leaving with it means combating them as they rear their ugly heads in the processes of government. But it seems that successive administrations have not been addressing these maladies with serious implications for growth, development and well-being of government and the people.

In Africa, transplanting (adopting developed countries' programmes and polices) structures, institutions and policies that began shortly after independence still persists to date with serious implications for people-centred development. It is instructive to note that institutions, policies and programmes from North America and Europe are products of certain cultural values that are largely Anglo-American in content. To swallow hook, line and sinker without the necessary adaptations have made them mere caricatures of their original form in their natural habitat. For example, in the 1960s and 1970s, modernisation as a platform for socioeconomic and political development in Africa failed to speed up development in Africa (Akhakpe 2014:328). Similarly, Structural Adjustment Programmes (SAP) did not succeed in revamping Africa's ailing economy. Presently, globalisation is seen as the anecdote for all-round transformation of mankind everywhere on the globe. But its differential effects in Africa and Europe are very clear. Its positives are yet to be fully domesticated in Africa perhaps; it may not be in concrete terms (Igbokwe-Ibeto 2018:121; Igbokwe-Ibeto, Osawe \& Alegbeleye 2014:619; Okoye, Igbokwe-Ibeto \& Anazodo 2015:6).

Public officials may embrace international best standards of administration, but putting them to work in the environment they operate may be another ball game altogether. The behavioural elements in every organisation are crucial to its success or failure. Even when some of the formal organisations 
we operate today did not come with their moral ethos, their operators run them with a system of moral hazard that makes them difficult to meet the common good (Akhakpe 2014:349). Efforts by successive governments in Africa to re-orientate public servants have not yielded many dividends as manifested in the spate of corruption, waste and maladministration in the public service.

Perhaps one reason that can be adduced for this state of affairs in the public sector is the conflict of interest between what public officials desire and the philosophy of the state government. Not many of the public bureaucrats and administrators believe (have confidence in the system) in Africa (Akhahpe 2014:322). For the majority of them, the African states remain an alien force, and abstract entity meant to be pillaged for personal and group gains. Thus, unity in the state is tenuous and delivery of services tokenistic. Everyone is in it for himself not for the good of all. The power elite is yet to agree on what the issues are and how they can be resolved in a frank and dispassionate manner for the good of all in the commonwealth. In the absence of distributive justice, poverty, social dislocation and economic immiseration are the order of the day. Those who are privileged to get to the precinct and corridor of power, see it not as opportunity to serve humanity but self, friends and relatives.

Perhaps it will take a long while to obliterate from the public sector and society in general, militarist values foisted on the body polity in the course of military rule in Africa. As they say, 'habit dies hard'. In the course of military rule, authoritarian values were imbibed, while due process, constitutionalism and the rule of law were abandoned (Akhakpe 2014:344). Infra-institutional approach to governance became the norm rather than exception, might become right, among others. This problem becomes acute when the military seized political power in most parts of Africa only few years after flag independence. Most institutions were not embedded enough in their routine and moral values, ethos and norms. Thus, whenever the military struck, democratic structures were dismantled, its institutions suspended and new values introduced into the politicosocial and economic lexicons (Akhakpe 2014:348). Once they hand over political power to civilians, another process of political socialisation and pedagogy is set in motion. Presently, politician and administrators are having enough time to learn and practice the act and science of liberal democracy.

Unfortunately, years of administrative reforms have not been able to inculcate in administrators the virtue of professionalism. To public servants, these reforms are only useful to the extent that they will improve their material conditions not their ability to impart on the people through efficient and effective services. Many of these reforms have taken place without fully reforming the public service and the way officials carry out their duties.

While most countries in Africa have embarked on these reform measures, their implementations leave much to be desired. Several reasons may account for the failure of some states to fully implement these reform measures. These, according to Akhakpe (2014:347), Dibie (2014:28) and Adamolekun and Kiragu (2002), include lack of political will on the part of its implementers, lack of resources to finance programmes in the state, payment of severance benefits to those affected by a down-sizing exercise and so on.

Duplication of roles, duties and functions that came with the expansion of bureaucracy and by implication public administration, several agencies and departments sprang up that carried out similar or the same responsibilities, thereby creating duplications and clash of responsibilities. This creates unnecessary delay and cumbersomeness in the discharge of government responsibility. Bureaucracy is reputed for extending its scope through the creation of agencies as a way of attracting more funding and increase in their budgets. Akhakpe (2014) argues that, unless this duplicity of roles is carefully harmonised, they have the potentials for inhibiting the efficiency and effectiveness of government activities.

Another issue of concern in the administrative system in developing countries is the declining importance of training and retraining of public servants. In the 1970s and 180s in Africa, training had a place of pride in public sector organisations. Public officials looked forward to training within and outside the country. Such training helped to equip public officials to keep abreast with current trends and standards of performance in their various areas of specialisation. However, since the 1990s, the craving for training and the interest in it have declined immeasurably (Fatile \& Igbokwe-Ibeto 2012:16). Workers in the public sector are no longer enthusiastic about training because to them, it does not count much. Either they cannot apply knowledge received from them or there are no opportunities to do so (Fatile \& Igbokwe-Ibeto 2012:18).

Also, morale in the public service is at its lowest ebb because of many factors, including poor reward system, failure to promote workers as at when due, poor remuneration, the premature retirement of competent and skilled personnel, the prevalence of ethnicism, nepotism and favouritism in the service (Fatile \& Igbokwe-Ibeto 2012:16). All these dampen the enthusiasm and zeal of public servants in the discharge of their responsibilities. Therefore, only a few public servants are dedicated to their job today. Many of them take up parttime jobs to make ends meet, while others engage in business even while in service, to complement their meagre salaries.

It would seem that the private sector is the chief beneficiary of the bad situation in the public sector, as it has willingly embraced the quality and experienced hands that have left the public sector in search for greener pastures outside. But positives from this development have not effectively been registered in the private sector in terms of driving it to champion growth and development of the economy especially in the areas of job creation and industrialisation of the economy. The public sector remains the largest employer 
of labour which is against the tenets of the new public management movement.

In all, the deficit in positive leadership is very glaring. The poverty of leadership in the public sector both at the level of bureaucrats and administrators has impacted negatively on the activities and actions of the administrative system. Leadership plays an important role in the performance and otherwise of public organisations. In the public sector, the lack of a critical mass of men of integrity is affecting the development stride of the governments at all levels (Akhakpe 2014:353). The public sector in Africa is presently dominated by a captive kind of leaders who are more interested in their personal interests than those of the generality of Africans.

\section{African bureaucracy and public administration: The prospects}

This article has identified impediments facing bureaucracy and public administration in Africa on a prima facie basis; these impediments may appear huge and complex. Yet, they are not insurmountable. Every impediment harbours an opportunity. This means, impediments identified in the preceding section of this discourse could be transformed into opportunities for African development. With concerted efforts, careful planning and dedication to the cause of Africa's development, what seems to be an ugly situation can be turned around for the good of all. In this section of the discourse, we shall examine some steps that could be taken to promote civil bureaucracy and public administration in Africa.

Global competitiveness demands that the civil bureaucracy step up its game to meet the demands of a dynamic and complex world. They must open themselves up to new ideas and international best practices that are constantly changing. This means that training and retraining should be prioritised (Fatile \& Igbokwe-Ibeto 2012:16). But while these innovations are daily flooding the continent, caution should be exercised in absorbing them all because bureaucrats may be chewing more than they can swallow. Therefore, there is a need for public administrators to incrementally apply only those measures that are friendly to conditions in the African society. The reason being that African countries are not at the same level of development as their homologue in Europe and North America (Akhakpe 2014:352). Also, their level of human and institutional capacities differs resulting in the natural differentials in abilities to embrace and internalise new measures and strategies in administrative systems (Dibie 2014).

Despite the clamour for reduction of the state's role in public management, in the context of Africa, this aspect of the administrative reforms should be viewed with caution because the private sector is perhaps too nascent to shoulder the responsibilities expected of it in the NPA movements. Africa for some years to come will have to provide leadership in supplying critical social services until such a time that the private sector will be mature enough to shoulder these responsibilities. Promoting efficiency and effectiveness in administration should be the watchword rather than pursuing the vogue in administrative systems in the West.

Africa can leverage on an attractive public sector with all the incentives to provide job satisfaction for its employees (Fatile \& Igbokwe-Ibeto 2012:18). The public sector can regain its lost glory by creating an enabling environment for its employees to bring out their best in service of their nation. Some of the ways of doing this is by building the institutional capacity to enhance the performance of these employees and the restructuring of the wages and salaries packages for public servants (Okoye, Igbokwe-Ibeto \& Osakede 2017:218). Through this, the public sector will begin to attract the best brains in the society and also retain those who come. No nation develops with a wobbly and demoralised public and civil service.

Leadership is vital for the rejuvenation of civil bureaucracy and public administration. Bureaucracy as agent of civilisation can achieve this goal if its vision and mission are channelled towards realising the common good rather than personal and corporate interests. Positive leadership that is creative and innovative is what is needed to redirect and redefine public administration for growth and development. The great nations of today had and still have their fair share of this calibre of leadership in both the civil and public services. This is what Africans need to break the vicious circle of development and underdevelopment.

Africa like other developing areas needs support from the external context to help realise some of its needs and programmes. Luckily, institutions and organisations abound in the international systems that are giving aid to countries restructuring their administrative systems. Sub-Saharan African countries have been benefiting from these aid agencies particularly the regional once, United Nations Development Programme (UNDP), Economic Development Institute (EDI) and International Labour Organization (ILO) have been on this (Akhakpe 2014:355).

The importance of transparency and accountability needs to be promoted in both civil bureaucracy and public administration. Accountability means that the state, private sector and civil society emphasise results, set clear objectives, put out strategies, monitor and report on what has been done. It tends to hold individuals and organisations responsible for performance judged objectively. Three dimensions work together to ensure that there is openness in the conduct of government business. These three dimensions are the following: financial accountability where public office holders report on how they use resources (Igbokwe-Ibeto 2017:331); political accountability dictates openness, sanctioning or rewarding those holding public positions through check and balances among the executive, legislature and judiciary; administrative accountability relates to systems of internal government control in areas of civil service standards, incentives, ethic code and administrative review (Cheema 2005; Vyas-Doorgapersad \& Aktan 2017; 
Vyas-Doorgapersad \& Keith 2009:10). Despite these provisions, there are still issues of clientelism, nepotism, tribalism, religious bigotry and corruption.

International organisations and donor agencies are expected to continuously provide much needed funds and technical assistance to these countries. But developing countries should be mindful of certain unfavourable conditions usually laid down by donor agencies for the release of funds.

\section{Conclusion}

The concept of African bureaucracy and public administration has been examined in an attempt to unravel this intellectual 'cobweb', as well as to analyse its normative impediments and prospects. In addition, the searchlight as a better understanding of the issues under investigation. Thus, the system theory underpinning the study has also been examined as postulated by scholars. An attempt has also been made to analyse the causal relationship between civil bureaucracy and public administration. Although they are sometimes seen as one and the same, analytically they can be separated.

One can deduce from the analysis in this article that civil bureaucracy is losing its potency and ability to give intellectual leadership to public administrators, particularly at the commission level. Many people find that the public administrators with whom they come into contact, rely too much on discretion that often does not sit well with the people and result in poor service delivery. All these could change if the bureaucracy opens up to administrative reforms particularly those that add value to their activities and actions. In the age of globalisation, international best practices are daily evolving, bureaucrats and public administrators should constantly be in touch and domestic global best practices suitable to their own condition and needs.

More than ever before, public administration is increasingly being called upon to fast-track the process of growth and development on the content of Africa and other developing countries of the world. This article is of the view that civil bureaucracy can help facilitate this process of bringing about all-inclusive growth and the reduction of poverty. This may not be done in one full-swoop but through the process of continuous reforms of the public administrative system, creative talents and experience of bureaucrats.

\section{Acknowledgements}

The author wishes to express his gratitude to God Almighty, the source of his strength, and to all those who directly or indirectly contributed towards the success of this article. The author specially mentions his Postdoctoral Research Fellowship (PDRF) host Prof. Nel Danielle of the School of Public Management, Governance and Public Policy,
University of Johannesburg, from whom he has drawn great inspiration and academic 'baptism'. Her guidance, support, constructive criticism and the professional manner in which she guided him through this study cannot be overemphasised. He is also grateful to all his family members and his colleges at the Nnamdi Azikiwe University, Awka, Nigeria, and indeed all the authors whose works were used which has been duly referenced.

\section{Competing interests}

The author declares that he has no financial or personal relationships that may have inappropriately influenced him in writing this article.

\section{Author's contributions}

The author did the entire research work.

\section{Ethical consideration}

All ethical considerations in a research of this nature were duly adhered to.

\section{Funding information}

Funding for this study was obtained from the University of Johannesburg.

\section{Data availability statement}

Data sharing is not applicable to this article as no new data were created or analysed in this study.

\section{Disclaimer}

The views and opinions expressed in this article are the author's own and do not necessarily reflect the official policy or position of any affiliated agency of the author.

\section{References}

Adamolekun, L., 1982, Public administration in Nigeria: A Nigerian and comparative perspective, Longman, London.

Adamolekun, L. \& Kiragu, K., 2002, 'Public administration reforms', in L. Adamolekun (ed.), Public administration in Africa: Main issues and selected country studies, pp. 42-43, Spectrum Books Limited, Ibadan.

Akhakpe, I., 2014, Bureaucracy and good governance, Pumark Nig Ltd, Lagos.

Anderson, J., 1997, Public policy making, Houghton Mifflin Company, Boston, MA.

Cheema, S., 2005, 'From public administration to governance: The paradigm shift in the link between government and citizens', paper presented at the 6th Global Forum on Reinventing Government towards Participation and Transparent Governance, Seoul, Republic of South Korea, 24-27th May.

Denhardt, R., Denhardt, J. \& Blanc, T., 2014, Public administration: An action orientation, Wadsworth Press, Boston, MA.

Dibie, R.A., 2014, Public administration: Theory, analysis and application, Babcock University Press, Ilishan-Remo, Nigeria.

Easton, D., 1953, The political system, Knopf, New York.

Fatile, O.J. \& Igbokwe-Ibeto, C.J., 2012, 'Nigerian public sector and the challenges of human capital development: The way forward', Scottish Journal of Arts, Social Sciences and Scientific Study 1(2), 11-23.

Gulick, L., 1969, 'Notes on the theory of organisation', in L. Gulick \& L. Urwick (eds.), Papers on the science of administration, p. 126, Augustus M. Kelly, New York. 
Igbokwe-Ibeto, C.J., 2017, 'Government and business relations in Tanzania', in R.A. Dibie (ed.), Government business relations in Africa, pp.314-339, Routledge Critical Studies in Public Management, London.

Igbokwe-lbeto, C.J., 2018, 'Globalisation and sustainable human development', in V. James (ed.), Capacity building for sustainable development, pp. 29-42, CAB International, London.

Igbokwe-lbeto, C.J, 2019, 'The effect of job analysis on service delivery in Federal Airports Authority of Nigeria (FAAN) 2005-2014', International Journal of Human Resources Studies 9(2), 195-211. https://doi.org/10.5296/ijhrs.v9i2.14745

Igbokwe-Ibeto, C.J. \& Anazodo, R.O., 2015, 'Managing executive-legislative working relationship for good governance and service delivery in Nigeria', Review of Public Administration and Management 4(8), 127-136.

Igbokwe-lbeto, C.J, Ajulor, O.V. \& Afegbua, S., 2012, 'Formal bureaucracy and development in Africa: The Nigerian instance', Global Journal of Applied, Management and Social Sciences 1(3), 103-117.

Igbokwe-Ibeto, C.J., Osawe, C. \& Alegbeleye, G., 2014, ‘Globalization and paradoxical position of Africa in the world economy', International Journal of Social Sciences and Humanities Invention 1(8), 612-626.

Jung, J., 1991, Rethinking administrative theory, Prraeger, Westport, CT.

Kettl, D.F., 2018, Politics of the administrative process, CQ Press, Los Angeles, CA

Koehier, J., Anatol, J.K. \& Applbaun, R., 1976, Organizational communication: Behavioural perspective, Holt, Rinehart and Winston, New York.

Lapalombara, J., 1974, Politics among nations, Princeton University Press, CQ Press.

Laxmikanth, L., 2011, Public administration, Tata McGraw Hill, New Delhi.

Milakovich, M. \& Gordon, G., 2013, Public administration in America, Wadsworth Press, Boston, MA.
Nicholas, H., 2010, Public administration and public affairs, Prentice Hall, Upper Saddle Rivers, NJ.

Okoye, J.C., Igbokwe-Ibeto, C.J. \& Anazodo, R.O., 2015, 'Globalization and its socioeconomic implications in sub-Saharan Africa', International Journal of Development Studies 6(2), 1-10.

Okoye, J.C., Igbokwe-lbeto, C.J. \& Osakede, K.O., 2017, 'Youth unemployment and human capacity development in Nigeria: The imperatives of entrepreneurship education', in Conference proceedings, Faculty of Management Sciences, Nnamdi Azikiwe University, Awka, 23-25th September.

Poliniadu, S., 2011, Public administration, Galgotia Publications Pvt. Ltd., New Delhi.

Robbins, S. \& Timothy, J., 2011, Organisational behaviour, 4th edn., Prentice Press, Upper Sadle River, NJ.

Rhodes, R., 1988, 'The institutional approach', in D. Marsh \& C. Stoker (eds.), Theories and methods in practical science, p. 62, Palgrave Publishers Limited, New York.

Shafritz, J., Russell, E.W. \& Borick, C., 2013, Introducing public administration, 9th edn., Longmans/Pearson Press, New York.

Sharma, M., Sadana, B. \& Kaur, H., 2012, Public administration in theory and practice, Kitab Mahal, Allahabad.

Simon, H.A., 1976, Administrative behavior, Free Press, New York.

Starling, G., 2013, Managing the public sector, Longmans/Pearson Press, New York.

Vyas-Doorgapersad, S. \& Aktan, C.C., 2017, 'Changing world and changing state: Rethinking the roles of the state', International Journal of Social Sciences and Humanities Studies 9(2), 80-94.

Vyas-Doorgapersad, S. \& Keith, S., 2009, 'The changing and challenging role of public administration: A universal issue', Politeia 28(2), 3-22.

Weber, M., 1947, The theory of social and economic organization, transl. A.M.B. Henderson \& T. Parsons, Free Press, New York. 